\title{
ReView Of Nano Technology Development IN TEXTILE INDUSTRY AND THE ROLE OF R \& D IN INDONESIA
}

\author{
Sudirman Habibie \\ Center of Technology for Material Agency for the Assessment and Application of \\ Technology
}

\begin{abstract}
The development of technology in the world, especially nanotechnology has also penetrated into the textile sector. The application of nanotechnology to textiles has given its own advantages compared to conventional textile technology. Nano technology has provided several advantages, such as: textiles with multiple functions, better quality, cheaper and environmentally friendly. Through the application of nanotechnology, types of textiles can be produced for many different uses, ranging from textiles to aerospace, aeronautic, automotive, sportwear, fire fighting, to defense and security such as parachutes, bulletproof clothes, and others. Thus for the Indonesian textile industry, in order to be able to compete with the textile industry from outside, it is also necessary to adjust to the development of global technology. The role of $R \& D$ institutions and universities is very strategic to develop nanotechnology where the industry is unable to do so given the shortage of human resources and research facilities.
\end{abstract}

\section{KEYWORDS}

Nanotechnology, Textile Industry \& Textile Product, $R \& D$ Institutions \& Universities.

\section{INTRODUCTION}

Population growth and the development of the world economy have encouraged an increase in the global textile industry. Competition takes place at the level of countries with cheap labor costs and technological development, which compete at cheap and expensive prices, good or not good quality. With the rapid advancements in technology, developed countries have been able to produce various types of textiles for a variety of uses, ranging from textiles to aerospace, aeronautic, automotive, sportwear, fire fighting, to defense and security such as parachutes, bulletproof clothing, and others.

The types of textiles above are produced in conventional / traditional ways that use a lot of chemicals, and many have a negative impact on the environment especially if dumped carelessly will cause pollution.

Innovations in the production, composition and application of textiles will be able to maintain stability in this sector. New technologies in textile processes and production will spur innovation in high-tech textile products. The new process will produce new products and therefore affect the DOI: 10.5121/antj.2019.5101 
Advanced Nanoscience and Technology: An International Journal (ANTJ), Vol. 5, No.1, March 2019

supply and production of traditional textile industries. Increasing globalization, new technology and growing demand for new products will change the textile market.

The tendency of the global textile industry seems to have pushed the existence of conventional textile businesses into a very difficult position in the current scenario. A number of competitors have invested enormous capital in high-speed technology, as a result, conventional textile products on the market at low prices cannot compete with products produced from more advanced technologies both in terms of quality and delivery. So that the high-tech industrial revolution is directly needed to survive in tight competition [1].

The global textile industry is moving further on developing of more promising technologies for producing textiles with functional properties and high performance including specialized coatings, such as: plasma-based products, smart technology and nanotechnology [2].

The impact of applying nanotechnology on the textile industry and the application of nanoscale materials to textiles has dramatically improved fiber technology and textile process technology to meet people's needs [3]. These drastic changes have been observed in the last 5 decades in textile applications and there is no doubt that in the next few years nanotechnology will penetrate into every field in the textile industry [4]. Nanotechnology is defined as careful manipulation of atoms and molecules individually to produce structures coated with different properties. Nanotechnology refers not only to the small size of the material used, but also to how it is engineered to perform certain functions [5]. To complete the application of nanotechnology in textiles, it certainly has the potential to become a revolution in the field of technical textiles. But there is a word of caution because the commercialization of industry from nanotechnology-based products can become a commercial reality [6].

\section{INNOVATION In TEXTILE FIELDS}

\subsection{TECHNOLOGY INNOVATION}

The textile industry is experiencing strong pressure on a very rapid change in the business environment, due to two main factors: (1) volatile markets and (2) intense competition in the world. For this reason, the textile industry needs to increase its ability to produce and market products with high added value and quality. This requires emphasis on new technology, design, creative marketing and management, where textile companies must learn and consider when and how to innovate.

An overview of global economic conditions like the following. The sales value of several major global industrial sectors can be seen in Table 1, where annual marketing is still dominated by tourism (US \$2,900 billion) and IT (US \$2,850 billion), while the textile industry is third with annual sales of US $\$ 1,620$ billion. Subsequently followed by the chemical industry (US $\$ 1,320$ billion), automotive industry (US $\$ 1,100$ billion), machinery industry (US $\$ 800$ billion) and military industry (US $\$ 800$ billion) [7]. 
Advanced Nanoscience and Technology: An International Journal (ANTJ), Vol. 5, No.1, March 2019

Table 1. Annual Sales of Major Global Industrial Sectors [7]

\begin{tabular}{|l|l|}
\hline Industrial Sector & $\begin{array}{l}\text { Annual Sales } \\
\text { (US \$ Billion) }\end{array}$ \\
\hline Tourism & 2900 \\
\hline Information technology & 2850 \\
\hline Textiles & $\mathbf{1 6 2 0}$ \\
\hline Chemicals & 1320 \\
\hline Automotive & 1100 \\
\hline Machine construction & 800 \\
\hline Military & 800 \\
\hline
\end{tabular}

Source: Syah, T., 2009

Taking into account the description in Table 1 above, the textile industry is expected to increase enormously in the coming years with consideration of increasing population and improving its well-being and lifestyle, thus demanding high-quality textile designs, style and quality. In Figure 1, several superior industries are shown to be innovating in the world, where the textile and fiber industries do the most innovation (28\%), followed by each by the chemical industry (14\%), research institutions (13\%) followed by other industries. Many technological innovations in the textile industry were triggered by the development of plasma technology, smart technology and nanotechnology.

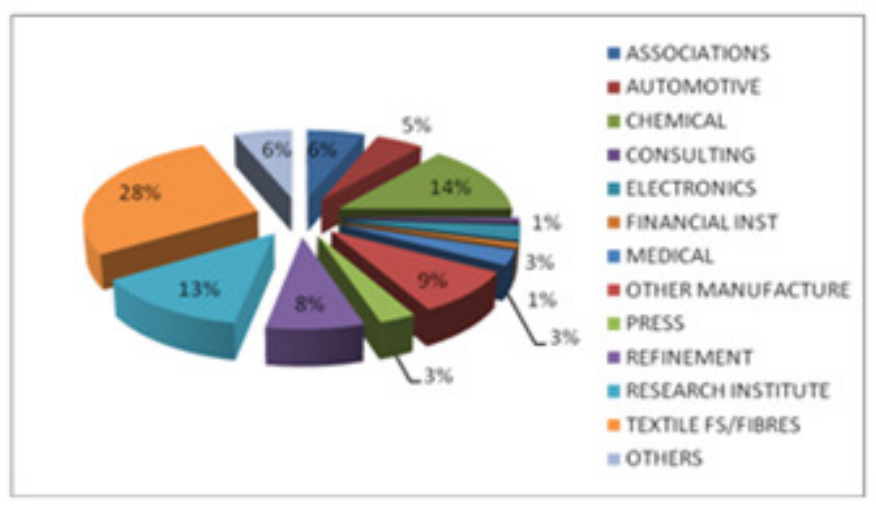

Figure 1. Some Industries in the World are Superior in Making Innovations [7]

Meanwhile, in Figure 2, it can be seen that the countries that are superior in the textile sector, first are Germany (44\%), Switzerland (13\%) and Belgium (10\%), while other countries are under 10\% and even America declares only 3\%. So that Germany has been supplying textile machines to Indonesia like Zulsler, etc. The advantages of German technology in the textile industry can be described as the biggest and they dominate fiber-making technology, spinning technology, weaving technology and printing technology. 


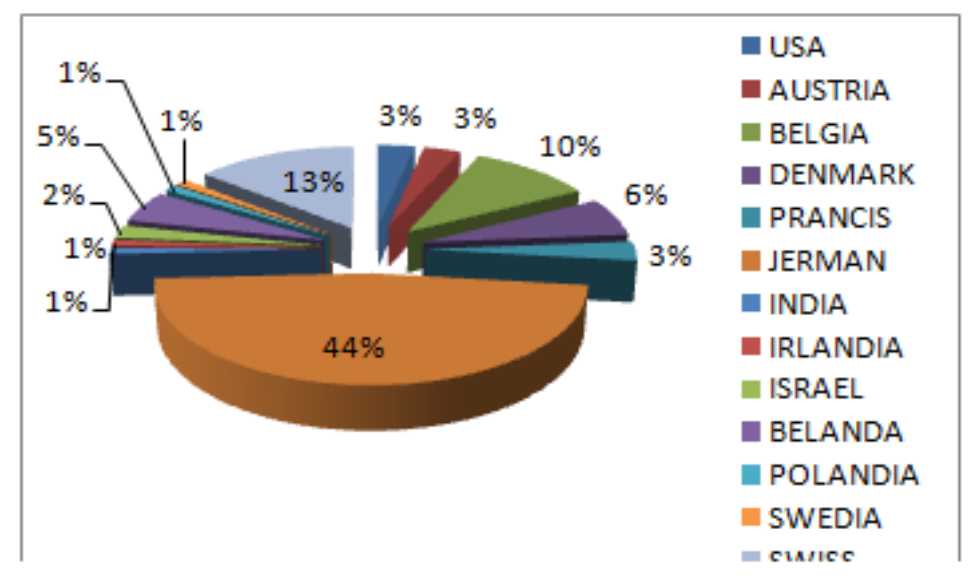

Figure 2. Some Superior Countries Innovating in the Textile Field [7]

Some increases in textile demand are caused by new technological innovations and added value of textile materials. Examples of several types of textiles are hydrophobic (water resistant), hydrophilic (water-friendly), anti-bacterial, barrier, breathability, antistatic, stretch, smart / intelligent, self cleaning, and others. Several factors influence the future generation of textiles,[4,7] namely: the first is raw materials, the possibility of using new polymers and renewable natural raw materials. Second is the production process, where a flexible, small batch process is needed, just in time and customized production processes. Third is textiles that have certain functions, such as: dynamic properties, anti-bacterial and microbial, self cleaning, smart textile and confort. As well as the fourth is a process that is friendly to the environment, for example using little water, using little energy, using little and no harm, operating conditions are not too tight, waste generated and the use of materials that can be recycled.

By spreading nanotechnology, fabrics that are very strong, durable, and have specific functions can be produced efficiently for a number of applications including medical, military and industrial clothing, etc. [8].

Nano technology brings opportunities and challenges for the textile industry which can make this big market more profitable and expanded. There is no doubt that in the next few years, nanotechnology will penetrate into every field of the textile industry [9].

\subsection{NANo TEChNOLOGY IN ThE TEXTILE INDUSTRY}

Nanotechnology deals with science and technology in dimensions of between 1 to 100 nanometers $(\mathrm{nm})$, see Figure 3. Where 1 billion nanometers is equal to 1 meter. For this reason $100 \mathrm{~nm}$ is a measure of practical performance for textile products and their applications. The growth of nanotechnology in the world naturally begins with the research and development $(\mathrm{R} \&$ D) of nanotechnology, where nanomaterial production will slowly and surely have an impact on every industry including textiles.

Currently nanotechnology in the textile industry continues to be developed and used, especially in several uses such as: soft fabrics (fabric softness), durable fabrics (durability) and closing power 
Advanced Nanoscience and Technology: An International Journal (ANTJ), Vol. 5, No.1, March 2019

(breathability), which have properties, such as: waterproof, fire resistant, antimicrobials, and others. Mejia et al. Conducted a study of the application of metal nanoparticles to textiles for hospitals which resulted in a reduction in microorganisms.[11]. Although much research has been done, more nanomaterials need to be found to realize new functions, and it is necessary to expand their applications to functional textiles such as sportswear, military clothing, and others.[12]. An overview of current developments and current trends relating to the use of nanotechnology in the sportswear industry, its shortcomings and future perspectives and current trends are given [13].

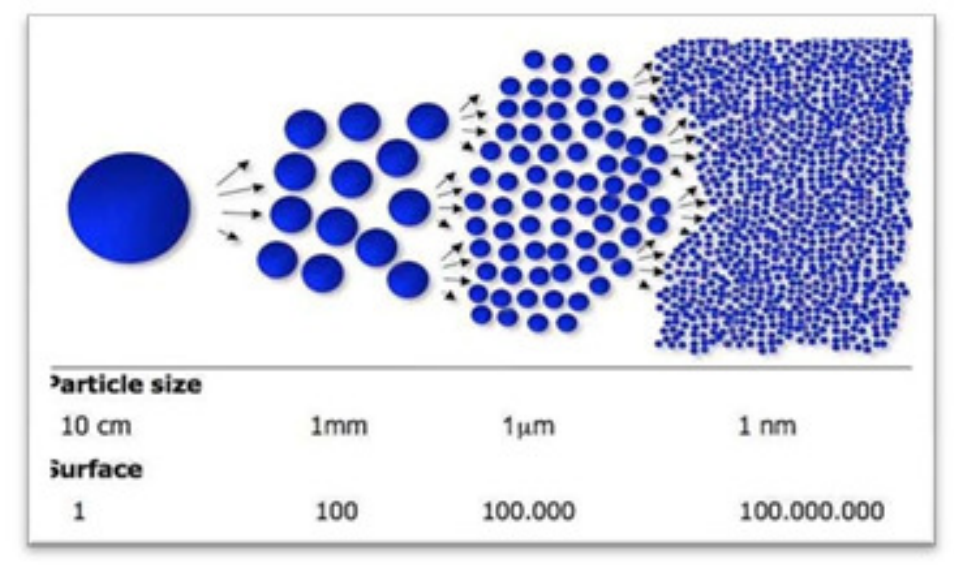

Figure 3. Size Image Scheme and Surface on the Nano Scale [10]

Currently nanotechnology in the textile industry continues to be developed and used, especially in several uses such as: soft fabrics (fabric softness), durable fabrics (durability) and closing power (breathability), which have properties, such as: waterproof, fire resistant, antimicrobials, and others. Mejia et al. Conducted a study of the application of metal nanoparticles to textiles for hospitals which resulted in a reduction in microorganisms.[11]. Although much research has been done, more nanomaterials need to be found to realize new functions, and it is necessary to expand their applications to functional textiles such as sportswear, military clothing, and others.[12]. An overview of current developments and current trends relating to the use of nanotechnology in the sportswear industry, its shortcomings and future perspectives and current trends are given [13].

\section{DEVELOPMENT OF THE INDONESIAN TEXTILE INDUSTRY}

The national textile industry is one of the largest non-oil and gas contributors to the nation, and is the second largest absorber of industry after the food industry, see Figure 4 [14]. The number of workers absorbed by the textile industry reached $2,796,131$ or $\pm 20 \%$ of the total workforce in the manufacturing industry. Thus the textile and textile products (TPT) industry can be relied upon as a large labor absorbing industry or labor intensive industries, especially in small and micro industries.

While the number of textile industries, especially medium-large scale increases every year. The mediumlarge scale TPT industry numbered 4,824 units in 2010 to 5,178 units in 2013 with an increase of 354 units over 3 years. The medium-large scale textile industry is a capital intensive industry, which utilizes many technological advancements.[15]. 
Advanced Nanoscience and Technology: An International Journal (ANTJ), Vol. 5, No.1, March 2019

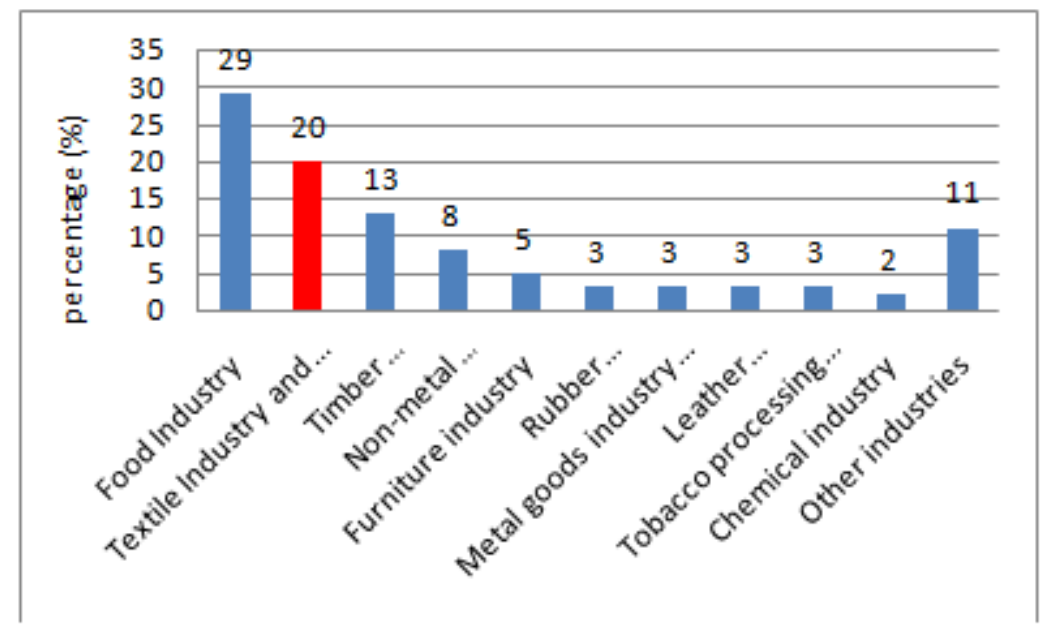

Figure 4. Total National Manufacturing Industry Workforce (including Micro Small Industry), is $14,117,019$ people in 2013 [14]

Therefore, considering these matters and the existence of considerable opportunities in the development of textile technology in order to compete in the international world, the development of the textile industry especially the application of nanotechnology is a necessity to help the national economy.

\subsection{Development Of The Innovation And Competitiveness Of The National TEXTILE INDUSTRY}

In general, Indonesia's competitiveness and innovation are still low in the world. Based on the 2013 Global Competitiveness Report, Indonesia's GDP per capita in 2013 increased from USD 3,015 in 2010 to USD 3,592 in 2012 [16]. So that Indonesia is classified as a country with a fairly efficient development movement. In 2014, Indonesia's competitiveness index of 4.57 was ranked 34 out of 148 countries, far below Singapore (2), Malaysia (20) and Thailand (31), see Table 2. Switzerland is in the highest position, followed by Singapore, USA, Finland and Germany which are the top 5 countries with high competitiveness [17]. The key factors for the success of economic development in these countries are the advancement of science and technology, the improvement of discovery and innovation, and the achievement of science and technology for economic development.

In Table 2 it can also be seen the ranking of countries with high levels of innovation in 2014 . Indonesia ranks 30th among countries in the world with a score of 4.20, Indonesia is in the third position after Singapore (11) and Malaysia ( 17), but better than Thailand (54), at the level of ASEAN countries. Based on data obtained from the World Economic Forum (WEF) in 2014, [18] there is a positive relationship between the growth of innovation and the economic growth of a country.

The empirical facts show that countries that have a low innovation index, GDP per capita is also low. On the other hand, an increase in the innovation index of a country will cause the country's GDP per capita growth. 
Advanced Nanoscience and Technology: An International Journal (ANTJ), Vol. 5, No.1, March 2019

Table 2. Global Competitiveness Index (2014-2015) [16]

\begin{tabular}{|l|l|l|l|l|l|}
\hline \multicolumn{6}{|l|}{ TABLE 2. GLOBAL COMPETITIVENESS INDEX (2014-2015) [16] } \\
\hline \multirow{2}{*}{ No. } & \multirow{2}{*}{ Country } & Competitiveness & \multicolumn{2}{l|}{ Inovation } \\
\cline { 3 - 6 } & & Ranking & Score & Ranking & Score \\
\hline 1 & Switzerland & 1 & 5,70 & 1 & 5,74 \\
\hline 2 & Singapore & 2 & 5,65 & 11 & 5,13 \\
\hline 3 & USA & 3 & 5,54 & 5 & 5,54 \\
\hline 4 & Finland & 4 & 5,50 & 3 & 5,57 \\
\hline 5 & Germany & 5 & 5,49 & 4 & 5,56 \\
\hline 6 & Japan & 6 & 5,47 & 2 & 5,68 \\
\hline 7 & Hongkong SAR & 7 & 5,46 & 23 & 4,75 \\
\hline 8 & Netherlands & 8 & 5,45 & 6 & 5,41 \\
\hline 9 & United Kingdom & 9 & 5,41 & 8 & 5,21 \\
\hline 10 & Sweden & 10 & 5,41 & 7 & 5,38 \\
\hline 11 & Taiwan & 14 & 5,26 & 13 & 5,11 \\
\hline 12 & Malaysia & 20 & 5,16 & 17 & 4,95 \\
\hline 13 & South Korea & 26 & 4,96 & 22 & 4,78 \\
\hline 14 & Thailand & 31 & 4,66 & 54 & 3,84 \\
\hline 15 & Indonesia & 34 & 4,57 & 30 & 4,20 \\
\hline 16 & Philippines & 52 & 4,40 & 48 & 3,90 \\
\hline 17 & Vietnam & 68 & 4,23 & 98 & 3,35 \\
\hline 18 & Cambodia & 95 & 3,89 & 116 & 3,15 \\
\hline
\end{tabular}

Low ranking shows that Indonesia's economic growth does not rely on competitive advantage in innovation (knowledge-based economy). From the export-import balancing data including the technology component announced by the OECD, it is explained that Indonesia's imports and exports are mostly dominated by low technology industries (OECD, 2012) [19]. This indicates that the competitiveness of Indonesian products is still low and requires $S \& T$ (Science \& Technology) injections and innovation.

It seems that future economic growth can no longer be based on natural resource benefits, but must be directed at increasing national capacity to produce high value-added commodities based on innovation. According to the WEF, [18] in order to achieve sustainable growth in innovation, contributions from the private sector are needed for $\mathrm{R} \& \mathrm{D}$ activities. This contribution is indicated by company spending on $\mathrm{R} \& \mathrm{D}$.

In 2013, the total national $\mathrm{R} \& \mathrm{D}$ expenditure amounted to Rp 8.09 trillion, where the government $\mathrm{R} \&$ D budget in 2013 amounted to Rp 5.102 billion, [13] or 74\%. Of the total government sector $\mathrm{R} \& \mathrm{D}$ expenditure (government research institutions amounting to 39\% and 35\% state universities) while the manufacturing industry sector contributes $26 \%$, see Figure 5. [20] Government R \& D expenditure is used for current expenditure of $71.34 \%$ and capital expenditure of $28.66 \%$. In 2013, the Gross Expenditure on R \& D (GERD) / GDP was 0.09\%. This is far from 1\% as mandated in MP3EI (Master Plan for the Acceleration and Expansion of Indonesian Economic Development). 


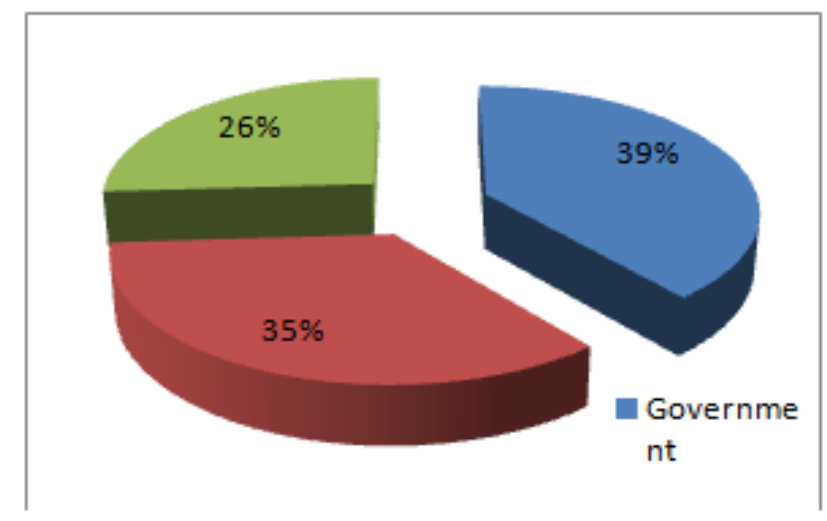

Figure 5. Higher Education Sector R \& D Expenditures, Manufacturing Industry and Government, 2013 [20]

Based on the WEF report, companies in Indonesia that spend on R \& D in rank 23 are brought by Singapore and Malaysia, see Table 3. When compared with other ASEAN countries, the company's expenditure ranking for Indonesian R \& D with GDP is ranked 23. Whereas Singapore ranks 8th and Malaysia ranks 17th (LIPI, 2013)[20].

Table 3. Corporate expenditure for R \& D in ASEAN countries, 2013 [16]

\begin{tabular}{|l|l|}
\hline Country & $\begin{array}{l}\text { Company Expenditure } \\
\text { Ranking for R \& D }\end{array}$ \\
\hline Singapore & 8 \\
\hline Malaysia & 17 \\
\hline Indonesia & $\mathbf{2 3}$ \\
\hline Philippines & 51 \\
\hline Vietnam & 59 \\
\hline Thailand & 60 \\
\hline Brunei & 67 \\
\hline
\end{tabular}

Source : The Global Competitiveness Report, 2013

The innovation process can also be influenced by collaboration between Universities (PT) and Industry. Both of these institutions can carry out R \& D together where PT has qualified human resources and laboratory facilities to conduct research and industry parties that have funds and development facilities, this needs to be supported by conducive government policies. Research collaboration in Higher Education and industry in Indonesia is ranked 30 out of 148 countries in the world, far behind compared to Malaysia ranking 16th and Singapore ranking 4. When among ASEAN countries, Indonesia's position is in third place under Singapore and Malaysia and above Brunei, Thailand, Philippines and Vietnam (Table 4). 
Advanced Nanoscience and Technology: An International Journal (ANTJ), Vol. 5, No.1, March 2019

Table 4. Collaboration between Universities and Industries in R\&D Activities in Several ASEAN Countries (2013) [16]

\begin{tabular}{|l|l|}
\hline Country & $\begin{array}{l}\text { Ranking of Collaboration of Universities } \\
(\mathrm{PT}) \text { and Industry in R \& D Activities }\end{array}$ \\
\hline Singapore & 4 \\
\hline Malaysia & 16 \\
\hline Indonesia & $\mathbf{3 0}$ \\
\hline Thailand & 51 \\
\hline Brunei & 65 \\
\hline Philippines & 69 \\
\hline Vietnam & 87 \\
\hline
\end{tabular}

Source : The Global Competitiveness Report, 2013

In the survey by LIPI, it was revealed that only $17 \%$ of respondents had R\&D collaboration with $\mathrm{R} \& \mathrm{D}$ institutions and universities, even the majority (83\%) of the companies carried out their own R\&D.

\subsection{R \& D Development And Transfer Of Technology In The TeXtile Sector IN INDONESIA}

The development and mastery of technology is needed by a nation and state in order to maintain the sovereignty of the country against the intervention of other countries both through the mastery of technology and economic independence. For countries that master technology, they will be free to develop any products that can be marketed in their country.

For Indonesia technology mastery is very important, if not Indonesia will be very dependent on external products. For that there is no other way for us to immediately improve ourselves, looking ahead to the mastery of technology through the development of R \& D in all fields. For the textile sector (TPT) the advantages of cheap labor have to be abandoned, because only shortterm oriented to pursue profits, while mastery of technology will lead to an increase in our competitive advantage towards other countries, especially in the field of textiles and textile products (TPT).

At present, the national textile industry has not been fully supported by $\mathrm{R} \& \mathrm{D}$ results both by the industry itself and by universities and national R \& D. Industry has more R \& D itself to improve the quality of their products, while higher education institutions such as Bandung Textile Polytechnic develop more HR as operators and maintenance.. While public universities and National R \& D have not significantly conducted R \& D in the textile sector. Though seeing the potential of the textile market and the existing textile industry, Indonesia is very potential to master this business.

Note, Indonesia's domestic market share is quite large with a population of about 250 million people in 2015 with average textile consumption about $2 \mathrm{~kg}$ per year (=14 meters of fabric), [21] so every year about 500 million $\mathrm{kg}$ or 3.5 billion meters are needed for fabric per year. At least mastering the domestic market alone will provide enormous employment opportunities. Whereas Indonesia's TPT exports have reached \pm US $\$ 12$ billion per year and employment reaches \pm 3 
Advanced Nanoscience and Technology: An International Journal (ANTJ), Vol. 5, No.1, March 2019

million people or $20 \%$ of the total workforce in the manufacturing industry. This is a large and strategic economic development potential if we use it optimally. But we must manage the superiority of Indonesia's position so that it is not used by other countries as a market for their products, including TPT products.

Therefore, textile education needs to be restructured so that it is oriented towards the development of R \& D so that graduates can help the industry. Although the results will not have an impact in the near future, but with continuous and consistent development of human resources, it is expected to catch up with other countries and then be able to excel in the development of technology and innovation in the TPT field that produces TPT products that excel in quality, design typical, and competitive prices.

The development of $\mathrm{R} \& \mathrm{D}$ in the field of textiles can begin with revamping educational institutions (especially textile colleges) that are oriented towards the education system to develop technology through research and development. Textile Polytechnic (Polteks) in Bandung can be developed not only to produce smart human resources to operate textile machines and design but also to innovate in developing new products. For this reason, it is necessary to have good teaching staff who have expertise in textiles (engineering and textile chemistry, as well as fiber) and teaching staff who are experts in the fields of information systems, computers, engineering, machinery, chemistry, design, polymers which collectives can make a breakthrough in the development of textile technology. If it is difficult to develop Polteks towards higher education with an R \& D orientation because of its nature as a vocational system university, it is necessary to establish a new tertiary institution (university) that specifically produces superior human resource products in the textile sector.

Besides that, it is necessary to immediately accelerate the technology transfer process, especially in the implementation of large projects and the procurement of imported machinery and equipment must be accompanied by a process of technology transfer. Indonesia in the New Order era was once known as a technology transfer model initiated by Prof. BJ Habibie (Republic of Indonesia's Third President). Prof. Habibie initiated the "technology transfer" at that time, known as "Starting from the end and ending at the beginning", [22] this concept is expected to accelerate technology transfer and mastery of technology for Indonesian children. This concept can be termed as a bit of stealing from other countries that have been done but is somewhat different because here the intended technology is purchased officially from developed countries through "License", then these products are modified and produce new products that have the advantages of the original product. The concept of technology transfer is known to have 4 stages, namely (1) license (2) technology modification (3) technology development and (4) basic research. Starting with the procurement of goods and technology through licenses, then technology modifications are made into new products that are different from the original ones, then technology development that produces new products is not yet available in the market and the last is basic research. In Phase 4, we are expected to be in line with other countries in mastering technology and new product innovations.

The acceleration of the technology transfer process and the development of quality human resources with superior educational backgrounds will have a rapid impact on the mastery of technology, especially textile technology, so that our textile industry can produce textiles and textile products with high quality and competitive prices. The impact is that we can compete and 
Advanced Nanoscience and Technology: An International Journal (ANTJ), Vol. 5, No.1, March 2019

dominate the domestic market, and still be able to compete in the international market, especially among other ASEAN countries.

\section{APPLICATIONS OF NANOTECHNOLOGY IN TEXTILE}

Nanotechnology-based textile applications are usually used in two ways, namely: (1) through finishing and / or coating of fibers or fabrics with nano-based materials, (2) through the manufacture of nanofibres (nanofibres) and or fibers containing nanoparticles. Both of these applications produce added value to textiles that are suitable for the purpose of use of these textiles, such as textiles for protective, healthcare, materials for fine clothing, for aerospace (for defense), for sports (sports), filter media (filter media), and others.

According to some researchers, nanotechnology is defined as the use of structures with at least one dimension of nanometer size from material construction, equipment or systems with new properties or significantly enhanced due to nano size. Nanotechnology not only produces small structures, but also the manufacturing technology anticipated can provide precision, inexpensive control of the structure. Nanotechnology can be better described as activities at the atomic and molecular level that have applications in the real world.

Nanotechnology also has real commercial potential for the textile industry. This is mainly because nanotechnology can provide a variety of desirable and long-lasting properties on fabrics, whereas in fact that conventional methods used to give different properties to fabrics often do not produce permanent effects, and will lose their function after hiwasng or use. Nanotechnology can provide high resistance to fabrics, because nanoparticles have a large volume to surface area ratio and high surface energy, so they provide better affinity for fabrics and result in increased resistance to their functions. In addition, coating nanoparticles on the fabric will not have an effect on breathability or hand feel. Therefore, the desire to use nanotechnology in the textile industry is increasing rapidly. The development of nano materials also creates new fabrication methods involving particle impregnation, spray coating, multi-functional composite fiber images, and direct weaving on an industrial scale [23].

So for this context the development of nanotextiles emerged. As mentioned, nanotechnology overcomes the limitations of the application of conventional methods to give certain properties to textile materials. There is no doubt that in the next few years nanotechnology will penetrate into every field of the textile industry [24].

\subsection{Finishing Process}

Coatings are a technique commonly used to apply nanoparticles to textiles. Coating compositions that can modify textile surfaces usually consist of nanoparticles, surfactants, ingredients and carrier media [25]. Several methods can apply coatings to fabrics, including spray, transfer printing, washing, rinsing and padding. From these methods, the most commonly used padding method [26-28]. Nanoparticles are applied to the fabric using padder which is adjusted according to pressure and speed, followed by drying and curing. The properties given to textiles use nanotechnology include water repellency, soil resistance, wrinkle resistance, anti-bacteria, antistatic and UV-protection, flame retardants, increased dyeability, etc.

One example of the application of nano technology is carried out by the Swiss textile company 
Advanced Nanoscience and Technology: An International Journal (ANTJ), Vol. 5, No.1, March 2019

Schoeller. The company has developed NanoSphere to make fabrics with water repellent properties. Impregnation NanoSphere includes a 3-dimensional surface structure with a gelforming additive that repels water and keeps dust particles from sticking. The mechanism is similar to the lotus effect that occurs in nature, as shown in Figure 6. Lotus flower plants have superhydrophobic surfaces that are rough and textured. When water drops fall on the surface of a lotus leaf, if the surface is tilted slightly, then the water will fall while carrying dust or dirt. Furthermore, the water point will take small particles and combine them and then bring them together, so that the leaves of the lotus plant remain clean even during heavy rain [25].

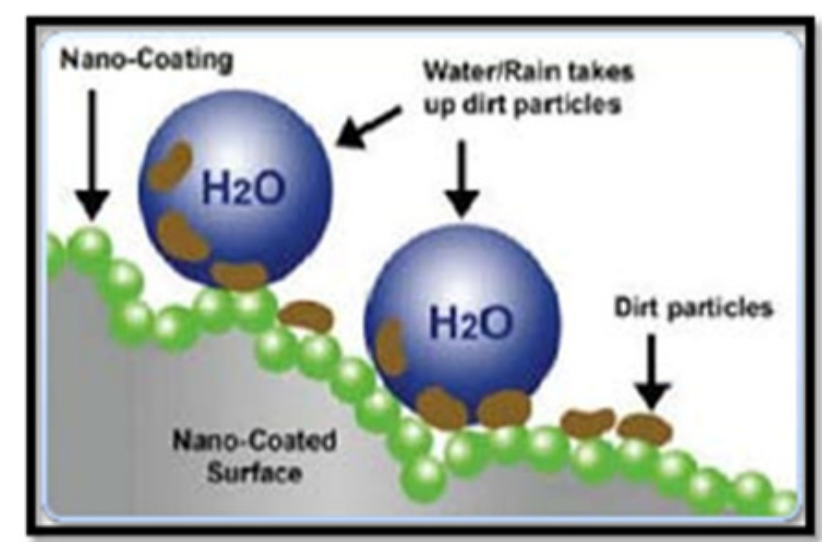

Figure 6. Improvement Mechanism Self-Cleaning Textiles with Nanocoated [29]

\subsection{MAKING NANO FibERS}

The application of nano technology can also be carried out through the manufacture of nano fibers (nanofiber). Nano technology is used to provide properties of nano fibers with high strength and lightness with multifunctional properties. Nano fibers have diameters ranging from 50 to $300 \mathrm{~nm}$. Making nano fibers can be produced with three methods as in Table 5. Of the three methods, the electrospinning method is the most widely used, perhaps because it is more simple and easy to operate.

Nano fiber can be used as a filter because of its high filtering speed which increases filtering efficiency even though it is used to filter out very small particles such as harmful bacteria.

Nano fiber is also used in the dyestuff industry for refining and removing salt. Other uses of nano fiber include producing materials for space shuttle (space shuttle) where the requirements for high strength to weight ratio. 
Advanced Nanoscience and Technology: An International Journal (ANTJ), Vol. 5, No.1, March 2019

Table 5. Method of Making Nano Fiber [30]

\begin{tabular}{|l|l|l|l|}
\hline Spinning type & Fiber Type & $\begin{array}{l}\text { Fiber Size } \\
\text { (micron) }\end{array}$ & $\begin{array}{l}\text { Fiber Size (in } \\
\text { denier) }\end{array}$ \\
\hline Electro-static spinning & Electrospun nano fibres & $0,04-2$ & $0,00002-0,06$ \\
\hline Melt blowing techniques & Melt blown fibres & $2-10$ & $0,03-1$ \\
\hline $\begin{array}{l}\text { Multi-component fibre } \\
\text { spinning }\end{array}$ & Spunbond fibres & $15-40$ & $1,5-12$ \\
\hline
\end{tabular}

An overview of current developments and current trends relating to the use of nanotechnology in the sportswear industry, its shortcomings and future perspectives and current trends are given [31].

\section{CONCLUSION}

The development of innovation in Indonesia is still very small compared to other countries (see Table 2), Indonesia is ranked 30th out of 168 countries surveyed in 2014, and conducted by Singapore (11) and Malaysia (17). For this reason, there is no other way than to speed up the technology transfer process and accelerate the development of $\mathrm{R} \& \mathrm{D}$ that leads to innovation products.

One innovation that needs to be developed in the national textile industry is the use of nanotechnology. Utilization of nanotechnology can replace conventional textile technology which utilizes many chemicals, energy and is less environmentally friendly. Nanotechnology in the textile industry can use 2 methods, namely finishing methods of textiles and manufacturing nano fiber. Besides these things, the use of nanotechnology will result in improved durability of textiles, washing resistance and wear resistance.

Indonesia needs improvements in service infrastructure and clear rules as a basis for technology development. Likewise the quality of higher education in science and engineering needs to be improved. Relations between universities and the private sector must be increased especially in the implementation of R\&D. The government must continuously promote innovation activities in science and technology and provide incentives for that. And improve policies to create a conducive innovation climate. Focusing on areas that are economically strategic and focused on developing R\&D. The government is also expected to be able to build a center of excellence that provides services at the education, $R \& D$ and implementation of workshops and training.

The government must create a conducive climate to create interaction between industry and universities and $\mathrm{R} \& \mathrm{D}$, where between these three institutions cooperate with each other that are mutually beneficial (win-win cooperation). Industries that have funds and development facilities while universities and R\&D have quality human resources, can utilize their respective capacities to produce new innovations that are useful for the development of science and technology. Then the industry can utilize the results of innovation to produce new products or scale-up new industries. For this reason, it is necessary to regulate the mechanisms and rules that support these interactions. 
Advanced Nanoscience and Technology: An International Journal (ANTJ), Vol. 5, No.1, March 2019

\section{REFERENCES}

[1]. .........., How to catch up with latest textile market trends Pakistan, Dawn News, July 17, 2006.

[2]. Hussain T., Textile Education in Pakistan, Pakistan Textile Journal, 2008.

[3]. Qian, L., Hinestroza J.P., Application of nanotechnology for high performance textiles, Journal of Textile and Apparel Technology and Management, Vol.4, 2004, p. 1-7.

[4]. Sinha A., N.V.T., Kelvin Y., Textile Industry review and outlook, Adsale ATA Textile Online Journal for Asia on Textile \& Apparel, Feb., 2011.

[5]. S. Karpagam Chinnammal *a, K.V.ArunKumar, NanoTechnology Application in Textiles, Journal of Nanoscience and Nanotechnology, Vol 2 (4), 2014, p404-406.

[6]. A.K.M. Ayatullah Hosne Asif* and Md. Zayedul Hasan, Application of Nanotechnology in Modern Textiles: A Review. International Journal of Current Engineering and Technology, Vol.8, No.2, 2018, p227-231.

[7]. Syah T., Innovation in Textiles : Trends and Challenges, CMRI, University of Bolton, UK, 2009.

[8]. SHIPRA KAUSHIK, Application of nanotechnology in textile, Asian Journal of Home Science, Vol 9 (2), December, 2014, p580-583

[9]. Rezwan Mahmud, Farhatun Nabi, Application of Nanotechnology in the field of Textile, IOSR Journal of Polymer and Textile Engineering (IOSR-JPTE), 2017, Vol 4, Issue 1, p 01-06.

[10]. Russell, E., Nanotechnologies and the shrinking world of textiles, Textile Horizons, 2002. 9/10: p.7-9.

[11]. M. L. Mejía $\Psi$, J. Zapata, D. P Cuesta, I.C. Ortiz, L.E. Botero, B. J. Galeano, N. J. Escobar, L. M. Hoyos, Properties of Antibacterial Nano Textile for Use in Hospital Environments. Revista Ingeniería Biomédica, Vol 11 (22), 2017, p13-19.

[12]. Yongho Choi, Sang-Duk Lee and Shin Hwan Yoo, Characteristics and application of nanomaterials on sportswear fabric, International Journal of Applied Engineering, Volume 12, Number 17 (2017) p. 6704-6709.

[13]. Geetika J, Vikas S Avinash C P. Nanotechnology in The Driver's Seat of Sportswear Industry: A Review of Current Trends and Future Applications. Trends in Textile \& Fash Design 2(4)-2018, p206-211.

[14]. ........, Kemenperind, Indonesia, 2014

[15]. ........, ITC, diolah API, 2014

[16]........., Global Competitiveness Report 2013/2014

[17]. ........, Global Competitiveness Report 2014/2015

[18]........., World Economic Forum, 2014

[19]........, OECD, 2012

[20]. .........., Buku Saku Indikator IPTEK 2014, PAPIPTEK-LIPI, 2014.

[21]. ........., API, 2016 
Advanced Nanoscience and Technology: An International Journal (ANTJ), Vol. 5, No.1, March 2019

[22]. ........., Pidato Prof. BJ Habibie, BPPT, 1978

[23] Ali K. Yetisen, Hang Qu, Amir Manbachi, Haider Butt, Mehmet R. Dokmeci, Juan P. Hinestroza, Maksim Skorobogatiy, Ali Khademhosseini, and Seok Hyun Yun, Nanotechnology in Textiles, American Chemical Society, 2016

[24] Kurapati Srinivas, The role of nanotechnology in modern textiles. Journal of Chemical and Pharmaceutical Research, 2016, 8(6), p173-180.

[25] Cramer, Dean, R., Ponomarenko, Anatolyevna E., Laurent, S., and Burckett, J.C.T.R., Method of applying nanoparticles, U.S. Pat. No: 6,645,569, 2003.

[26] Anonymous, Small-scale technology with the promise of big rewards, Technical Textiles International, 2003, 3, p 13-15.

[27] Xin, J.H., Daoud, W.A., and Kong, Y.Y., A New Approach to UV-Blocking Treatment for Cotton Fabrics, Textile Research Journal, 2004, 74, p 97-100.

[28] Yeo, S.Y., Lee, H.J., and Jeong, S.H., Preparation of nanocomposite fibers for permanent antibacterial effect, Journal of Materials Science, 2003, 38, p. 2143-2147.

[29] Chinta S.K., Landage S.M., Jain Swapnal, Water Repellency Of Textiles Through Nanotechnology, International Journal of Advanced Research in IT and Engineering, Vol. 2 | No. 1 | January 2013.

[30] Malik, T. dan Singh, H.K., Nanotechnology: An Energing Field in Textiles, International Journal of Advanced Technology \& Engineering Research (IJATER), E-ICETT, 2013, p6-9.

[31]. Geetika J, Vikas S Avinash C P. Nanotechnology in The Driver's Seat of Sportswear Industry: A Review of Current Trends and Future Applications. Trends in Textile \& Fash Design 2(4)-2018, p206-211. 